\title{
The Views of Social Studies Teacher Candidates on Coding and Production of Educational Materials through Coding
}

\author{
Mustafa Dolmaz \\ Independent Researcher, Turkey
}

Copyright@2019 by authors, all rights reserved. Authors agree that this article remains permanently open access under the terms of the Creative Commons Attribution License 4.0 International License

\begin{abstract}
The aim of this research is to determine the views of social studies teacher candidates on coding and production of educational materials through coding. In the research, document review method, which is one of the qualitative research methods, was employed. A puzzle produced by coding has been examined by teacher candidates. Then, 8 questions were addressed to 40 teacher candidates in order to receive their views through interview forms. Data obtained from the interview form were analyzed by content analysis. When calculating the reliability of the research, the reliability formula developed by Miles and Huberman [20] was used. As a result of the research, it was determined that teacher candidates do not have the knowledge of coding in general, that there is no teacher candidate who produces material by coding except one teacher candidate, but that the majority of teacher candidates want to learn coding. In the views of a majority of teacher candidates, it was revealed that it would be appropriate to give coding education in the high school period. The material produced by coding was found to be simple, fun, informative, summarizer and effective by teacher candidates. Teacher candidates think that such materials are low cost, reusable, attractive, functional and easy to distribute materials, however, they believe that coding has disadvantages such as technical equipment requirement, the high cost of ready-to-use software fees, and a negative impact on students' health.
\end{abstract}

Keywords Coding, Educational Material, Social Studies, Material Production with Coding

\section{Introduction}

The use of information technologies in today's schools, education and teaching activities has brought a new breath to education, and has provided teachers and students with a fun, interesting and more useful way to process the lesson using materials based on information technology $[10,14,25]$. Initially, information technologies (IT) were only used as a complementary/reinforcing tool for the education system. However, when the principle of self-learning is combined with computer technology, the computer becomes an environment in which learning occurs in education [4].

Computers do not have functional brains and work with commands written by humans. We name this special language, which we use to process commands on the computer, the programming language [18]. Several programming languages have been developed to develop solutions for different needs. Each language consists of its own phrase, spelling rules and commands. Coding, on the other hand, is defined as "the process of writing language-specific commands". In short, the equivalent of commands given to the computer in programming is code and the whole codes that create computer software are defined as coding [11]. The fact that computer becomes an environment in which learning occurs, makes it necessary to benefit from the coding / programming technology, which existed in various fields from the defense industry to the economy, in educational activities. The introduction of e-school, e-education or online education, especially in recent years, is a result of the educators' efforts to benefit from web-based platforms formed by coding based on information technologies.

The existence of coding technology in every field of life made coding/programming education important in many countries in the 21st Century as it facilitates daily work and operation in many fields from the business world to the educational world and the coding skills have started to be accepted as a competence that each individual should have. In fact, "coding in many sources is now considered a part of logical reasoning, which is one of the 21st century skills" and expected by each individual to have $[9,24]$.

Today, children meet technology from the age of three 
and spend more time on the internet than their parents. Therefore, in the future, the first step in the training of the qualified labor force needed by society in every field will be to teach the children to code [29]. Children receive programming education from the age of 7 in Estonia, software education from primary school in South Korea, and computer programming education from the age of 5 in the UK since 2013; and in the UK, a 5-year-old child is learning how to store and organize data and how to code a simple program. In Europe, there are even "European Code Week" activities to turn young Europeans into creative individuals [7].

In Turkey, in the 2012-2013 academic year with the changing education system to $4+4+4$, information technologies and software courses for secondary schools have been added to the curriculum. Since the 2013 - 2014 academic year, these courses have been given as compulsory courses in the 5th and 6th grades, and as elective courses in the 7th and 8th grades [17].

When the special aims of information technologies and software courses are examined, the students in 5th and 6th grades are aimed:

- To access internet-based services, research and use,

- To acquire and improve their problem-solving and knowledge-based thinking skills

- To acquire collaborative work skills as part of the learning process, benefit from social environments and share what they have learned,

- To search for learning opportunities in the Internet environment,

- To be able to use at least one of the programming languages,

- $\quad$ To be able to apply the appropriate programming approach to solve problems,

- To carry out studies on product design and management,

- To develop innovative and original projects for solving everyday problems (problems faced by elderly and disabled individuals, etc.),

- To gain awareness of lifelong learning [19].

It is of great importance to raise a productive and creative generation in the solution of the problems of contemporary society and the electronic world. It is imperative to give coding / programming education to children from an early age in order to raise a creative generation [23]. Coding helps students develop skills such as problem solving, spatial and analytical thinking, logical thinking, digital thinking, creative and critical thinking, and is also very effective in developing a positive attitude towards the classroom and school [7,21,24].

The attitudes and skills of teachers in technology and material use are very effective in students' learning. However, it is ideal for teachers to prepare their own course materials. With the materials used in education, the more it is addressed to the sensory organs of the students, the more effective, meaningful, permanent and fast education takes place [30,31]. Materials that are based on coding are highly effective materials that appeal to a large number of sensory organs.

Teachers' levels of use of information and communication technologies in material development are very important. For this reason, as well as teachers integrating technology into education, it is inevitable that they have to acquire the ability to develop technological materials [32].

Coding skills are like a play dough for individuals who have these skills. Using the coding skills, a variety of teaching materials can be created by students and teachers. For example, a student or teacher who knows coding will not have any difficulty in creating learning and teaching materials such as various educational games, animations, simulations, puzzles, mobile applications, social networks and blog pages that can be used for the purposes of the course within or outside the classroom environment. In this case, materials that can be used in the educational environment are limited to the imagination of students and teachers, in other words, countless instructional materials can be produced through coding.

Coding skills, in particular, are seen as technology literacy skills as of today [33]. The role of pre-service education, on the other hand, plays a big part for teachers to be able to design materials based on IT technologies [34]. Here, pre-service education refers to university education and the individual learning efforts that take place during university education. The more equipped the candidate teachers become during the pre-service period, the more the students have learning outcomes. For this reason, the research was carried out on candidate teachers. The research is important in terms of drawing the current situation to us by revealing the views of the candidate teachers of social studies course in the near future on coding skill levels, coding and material production based on coding.

Researchers working on coding education have often studied how to give coding education, why to give it, what educational grade to give it, and the resources to which students can learn coding. It is determined that no study was conducted on material production through coding. However, it is possible to produce highly effective teaching materials for almost every course through coding.

The aim of this research is to determine the views of social studies teacher candidates on coding and production of educational materials through coding. In this regard, answers will be sought to the following questions:

1. What is coding according to teacher candidates?

2. What is the coding level of teacher candidates?

3. Are teacher candidates willing to learn coding?

4. Which grade of education should the coding course be given according to teacher candidates?

5. Did teacher candidates produce coding-based material? 
6. What does the teacher candidates think about the puzzle produced by coding?

7. What are the advantages of the material produced by coding method according to teacher candidates?

8. What are the disadvantages of the material produced by coding method according to teacher candidates?

\section{Materials and Methods}

\subsection{Method}

The research was conducted by adopting qualitative research pattern. Research conducted by qualitative research method allow researchers to present research results based on codes and categories [35]. In this context, document review method, which is one of the qualitative research methods, was employed and interview forms including the views of candidate teachers were examined with document review method. Document review enables the analysis of documents produced by multiple sources about a research problem in a given time period $[36,28]$.

\subsection{Materials}

\subsubsection{Interview Form}

It is prepared by the researcher following a comprehensive literature survey. The final shape of the form is given in line with the views of three field experts. Structured interviews are designed using a set of predefined questions to reveal participatory thoughts, ideas and attitudes about the study topic. In other words, the questions are asked in their predetermined forms, without any room for flexibility, and all participants are asked the same questions [6]. The purpose in such interviews is to provide participants with approximately the same stimulus and thus to obtain the answers to the questions in a comparable format [3].

The questions in the interview form are:

1. What is coding?

2. Do you have coding knowledge? If so, which level do you know?

3. Would you like to learn coding?

4. Should the coding course be included in educational curricula? If so, which level of education should the coding course be given?

5. Have you ever produced material through coding?

6. What do you think about the sample material (puzzle) produced by coding?

7. What are the advantages of the research material produced through coding?

8. What are the disadvantages of the research material produced through coding?

\subsubsection{Coding-Based Puzzle}

To create a sample material produced through coding, the EclipseCrossword 1.2.61 package program [40] was employed. The puzzle is coded in the "Java" language and as embedded in an "html" page is created by program. The puzzle created includes 17 questions in total within the context of "Ülkeler Arası Köprüler" unit, the seventh unit of seventh grade social studies course. When determining the questions included in the puzzle, a balanced distribution is observed between the subjects and after taking the views of experts, the puzzle is created and presented to teacher candidates.

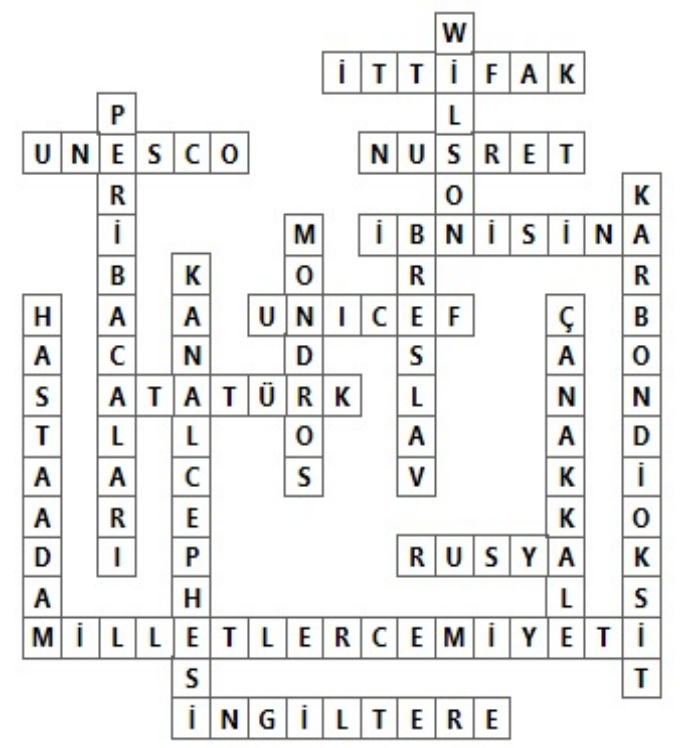

Picture 1. Solved coding based puzzle

\subsection{Study Group}

The study group of the research consists of 40 teacher candidates who have graduated from the faculty of education, social studies education department. In determining the study group, criterion sampling, which is a kind of purposive sample, was used. "In a research, criterion sampling can consist of individuals, events, objects, or situations that have specific qualifications in their observation units" [5]. For this research, graduation from a faculty of education and having basic computer skills are defined as the criteria.

All of the candidate teachers who participated in the study are graduated from the "Department of Social Studies Teaching" at the Faculty of Education and are waiting for their appointment. The research was carried out in 2018 with 40 candidate teachers in Sivas and Ankara provinces prepared for KPSS (Public Personnel Selection Examination).

Some descriptive information about candidate teachers were given in Table 1, Table 2 and Table 3. 
Table 1. Gender Information Of Candidate Teachers / Provinces They Live

\begin{tabular}{ccccc}
\hline \multirow{2}{*}{ Province } & \multicolumn{4}{c}{ Gender } \\
\cline { 2 - 5 } & \multicolumn{2}{c}{ Male } & \multicolumn{2}{c}{ Female } \\
\cline { 2 - 5 } & $\mathrm{N}$ & $\%$ & $\mathrm{~N}$ & $\%$ \\
\hline Ankara & 6 & 15 & 21 & 52.5 \\
\hline Sivas & 8 & 20 & 5 & 12.5 \\
\hline Total & 14 & 35 & 26 & 65 \\
\hline
\end{tabular}

13 of the teacher candidates participating in the study live in Sivas Province and 27 of them live in Ankara province. 8 of the candidate teachers from Sivas province are male and 5 are female. In Ankara, a total of 27 people, 6 male and 21 female, participated in the study. The total number of female teacher candidates participating in the study is 26, and the number of male teachers is 14 .

Educational backgrounds of teacher candidates are given in Table 2. 7 of the candidate teachers have a postgraduate degree and 33 of them have a undergraduate degree.

Table 2. Information on The Educational Background Of Candidate Teachers

\begin{tabular}{ccc}
\hline Educational Background & $\mathrm{N}$ & $\%$ \\
\hline Undergraduate & 33 & 82.5 \\
\hline Postgraduate & 7 & 17.5 \\
\hline Doctorate & - & 0 \\
\hline Total & 40 & 100 \\
\hline
\end{tabular}

Tablo 3. Distribution of Teacher Candidates' Age Range

\begin{tabular}{ccc}
\hline Age Range & N & $\%$ \\
\hline $21-23$ & 5 & 12.5 \\
\hline $23-25$ & 23 & 57.5 \\
\hline $25-27$ & 7 & 17.5 \\
\hline $27-29$ & 5 & 12.5 \\
\hline
\end{tabular}

When the distribution of candidate teachers by age groups was examined, it was observed that four groups were divided into 21-29 age groups. There are 40 candidate teachers in all groups, 5 candidate teachers in age range 21-23, 23 candidate teachers in age range 23-25, 7 candidate teachers in age range 25-27, and 5 candidate teachers in age range 27-29.

\subsection{Collection and Analysis of Data}

The data were collected through the interview form developed by the researcher. Using the coding-based puzzle, teacher candidates expressed their views on coding and coding-based material production through this form. Data collection and analysis with interview form lasted approximately 3 months.

In qualitative data analysis, the qualitative data analysis program MAXQDA 12 was employed, the theme categories determined by the program are also transferred to the Excel environment with the same program and thus, the numerical values of code themes have been obtained. These numerical values are presented in the findings part of the research in charts.

Content analysis method was used in the analysis of data obtained through forms. The main purpose of the content analysis is to find concepts and relationships that can explain the collected data. In this context, the collected data is conceptualized first and then is organized according to the emerging concepts. In the last step, the process of determining the themes (categories) that explain the data organized around the concepts is carried out [28]. In other words, content analysis is a systematic analysis and a definition of oral or written materials in general and in its essence lies the categorization of what is said or written $[37,38]$.

In the analysis of the data, the validity study was carried out by asking the opinions of three field experts, other than the researcher. For the reliability study, the categorization process performed by the researcher was compared with the categorization done by the field experts. In the calculation of the reliability of the research, the reliability formula [Reliability = Consensus / Consensus + Disagreement x 100] developed by Miles and Huberman was used [20]. In this study, the consensus was determined as $89 \%$ for coding/categorization by the researcher and field experts. $70 \%$ or more of the consensus/agreement is sufficient for the reliability of the data.

\section{Findings}

In this part, the responses given by the teacher candidates to the questions they were asked in interview forms and findings obtained for the purposes of research are listed as graphics coded in themes. In addition, sample views of candidate teachers, who constitute the study group, coded with code numbers between 1-40 using the abbreviation CT (candidate teacher) are included in this section.

\subsection{Findings of What Coding Is}

When the answers to the question 'What is coding?' from the sample group are categorized, we see four categories.

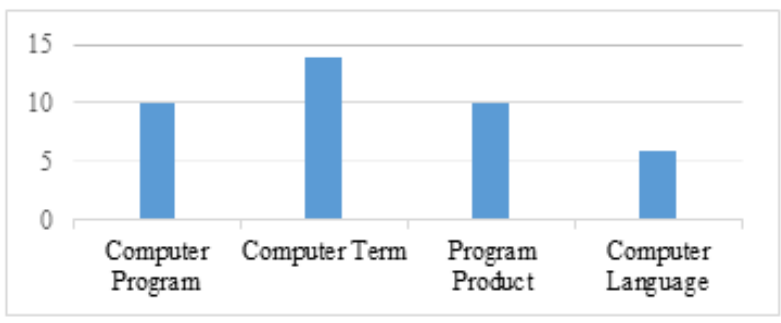

Chart 1. What is the Coding? 
These categories are given in Chart 1 . According to the chart, out of a total of 40 teacher candidates, 10 identified coding as a computer program, 14 as a computer term, 10 as a program product, and 6 as a computer language.

When the theme categories are looked at, the most common theme we come across is the theme category in which coding is defined as a computer term with fourteen frequencies. The least encountered theme, on the other hand, consists of responses that define coding as a computer language. Among the responses, there was no expression that defines the coding flawlessly. Some responses given by candidate teachers are given below.

CT3: "I know that coding is a computer language, I've heard of it before. Programs are created by coding and these programs are used to control robots or electronic devices. But that's all I know. I don't know how to code.”

CT7: "I've read a variety of articles on what coding is in some art and science magazines. I guess it's some kind of a computer program. I had no interest in coding. Branch teachers who are interested in information technologies can respond to this question more accurately."

CT28: "I may not be able to make a clear definition, but programs are created by coding and the task is carried out by the programs commanded by the people using these programs."

CT6: "I don't want to make a wrong definition, but I know it's a computer language."

Although these statements suggest that candidate teachers are not able to accurately define what coding is, given the responses they expressed, it can be said that the responses of a few candidate teachers in making the coding definition are at a satisfactory level. The visual results obtained from the Maxqda program for the findings in this section are given below. The line thickness that is clearly seen in the visual is directly proportional to the frequency of the code categories that appear with the preference of teacher candidates.

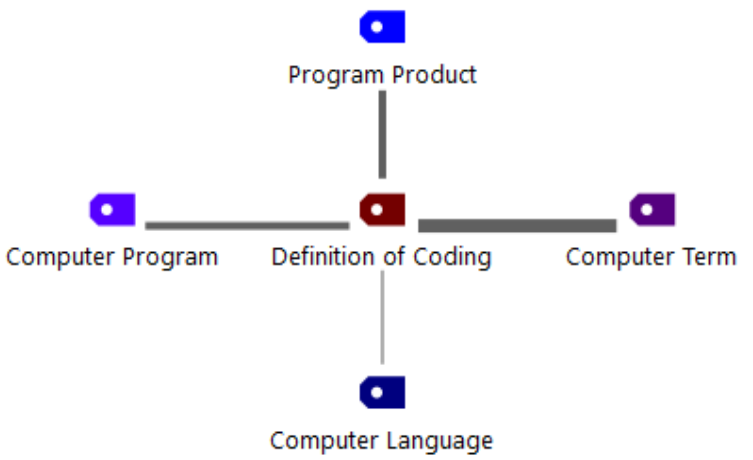

Figure 1. What is the Coding?

\subsection{Findings on the Coding Knowledge Levels of Teacher Candidates}

In the second question in the interview form, the teacher candidates were asked whether they have coding knowledge. As seen in Chart 2, 90\% of teacher candidates (36 people) stated that they have no coding knowledge.

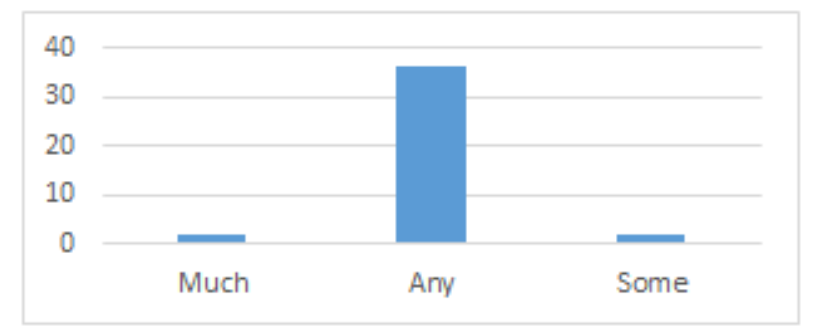

Chart 2. What is your coding knowledge level?

Only two teacher candidates stated that they have coding knowledge. This number constitutes only $5 \%$ of the sample group. The proportion of those who have some coding knowledge also constitutes $5 \%$ (2 people) of the group.

When the theme categories of candidate teachers for their coding knowledge levels are examined, it is observed that vast majority of candidate teachers do not have coding knowledge. Sample views of candidate teachers are given below. For example:

CT15: "I don't know how to code. I don't have much interest in computers, so it's not appealing to me. I'm currently using the computer to do some basic tasks, but I'm just a regular user."

CT26: "I've never received coding training in my entire period of study. I personally did not spare much time for this. Therefore, it wouldn't be wrong for me to say I have no knowledge of coding."

CT13: "I don't know how to code. And I never needed to learn it."

CT9: "I know HTML and PHP at beginner level. I try to improve myself when I find the time. Recently, my interest in coding has increased.” The candidate teacher coded CT9 has been observed to be in an effort to improve herself and it can be understood from the teacher's willingness to learn coding and having a few ideas about coding from her response to the relevant question of the research.

Of course, the most important point that attracts attention here is that teachers do not have the coding knowledge. In fact, this is directly related to the situation 'why the definition of coding cannot be made by candidate teachers' given in the first question. A large majority of candidate teachers have failed when making the definition of coding, since they do not know coding. 
The table will be understood clearly when looked at candidate teachers' coding knowledge, which constitutes the basis for determining theme categories The visual results obtained from the Maxqda program for the findings in this section are given below.

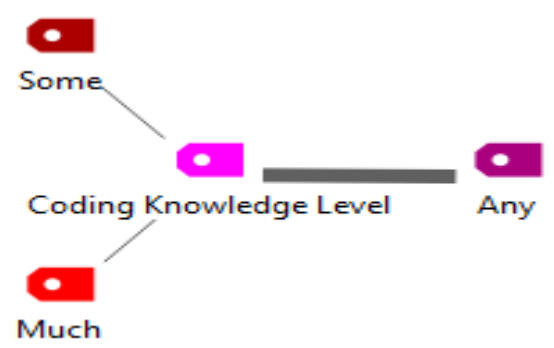

Figure 2. What is your coding knowledge level?

\subsection{Findings on Teacher Candidates' Willingness to Learn Coding}

As the data in the chart 3 shows, 34 teachers are willing to learn coding. The number of candidates who stated that they do not want to learn coding is 6 . As it is understood from Chart 3, the majority of teacher candidates are willing to learn coding.

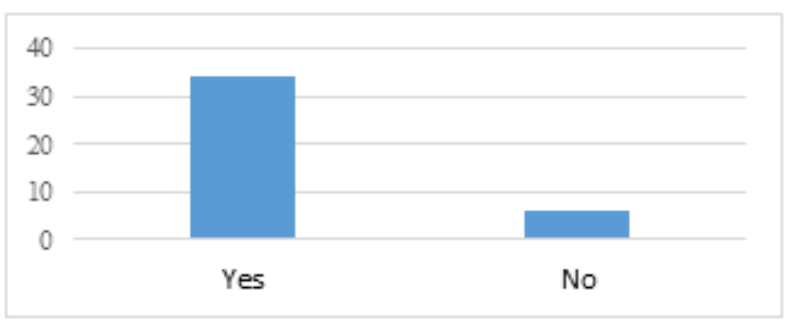

Chart 3. Would you like to learn coding?

When the theme categories for the willingness of candidate teachers in learning coding are examined, it can be seen that candidate teachers are quite willing to learn coding. The fact that 34 of the candidates from 40 candidate teachers want to learn coding is an indication that they do not have a negative attitude towards coding in general. This willingness can be seen more clearly when the views of various candidate teachers towards this theme are examined as examples. For example;

The candidate teacher coded CT1 has stated that he is willing to learn coding with the help of an instructor in his statement "Of course I do, but I cannot learn easily on my own and I don't have the infrastructure. I can spare time to attend a course."

The candidate teacher coded CT4 expressed his willingness to learn coding with his expression "Yes, I want to learn coding. Coding knowledge turns into a need each passing day, and I think it already became a need."

Again, in the sample statements given below, it can be seen that candidate teachers want to learn coding in general.

CT37: "I'm preparing for KPSS examination. I'd like to learn if I could spare some time, but it seems impossible for now."

CT10: "Yes, I want to learn coding. Which teacher or candidate teacher doesn't want to learn anything new?"

CT12: "I don't have learning coding in my short-term plans, but I don't see why not in the future?"

The teacher candidates who do not want to learn coding have justified their reluctance as;

- 2 of them as time constraints,

- 1 of them as economic conditions

- 2 of them as the unnecessity of coding

- 1 of them as their unwillingness towards learning coding

The teachers who want to learn coding, on the other hand, stated their willingness to learn coding as;

- 1 of them as it is useful,

- 3 of them as it is a skill

- 21 of them as it's a necessity

- $\quad 9$ of them as they are willing to learn

The visual results obtained from the Maxqda program for the findings in this section are given below.

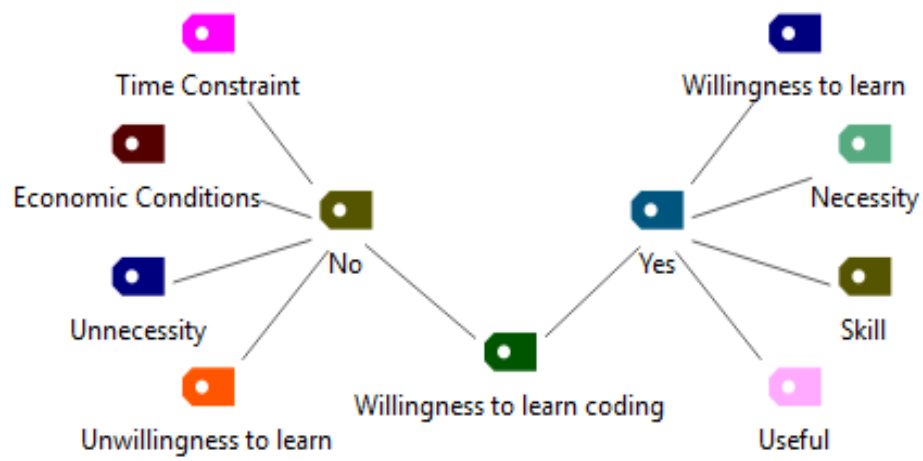

Figure 3. Would you like to learn coding? 


\subsection{Findings on the Views of Which Level of Education Coding Should Be Taught}

The teacher candidates' responses to which level of education coding should be taught are given in Chart 4 .

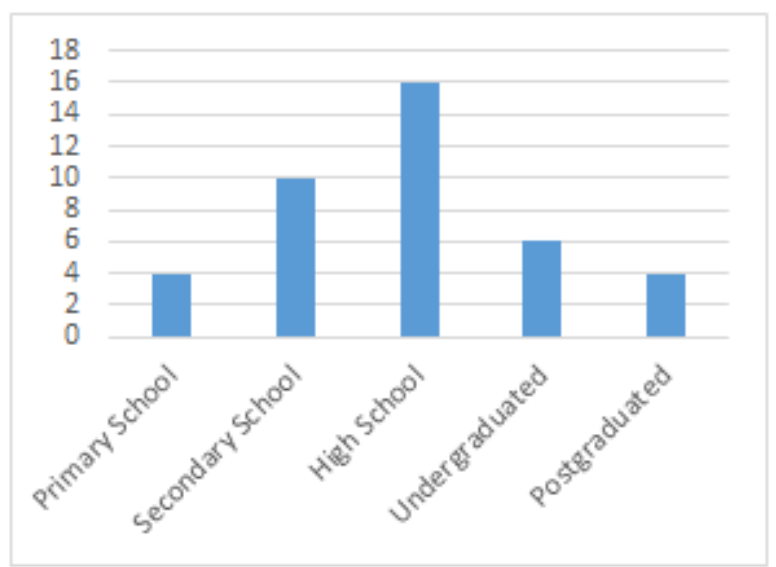

Chart 4. Which level of education should the coding course be given?

As it is understood from this chart, about $40 \%$ of the teacher candidates stated that this education should be given at the high school level. 25\% (10 people) of the candidates agree that it would be appropriate to start teaching coding in secondary school. The number of teacher candidates that indicate the coding education should start at the primary school level is equal to those who stated that it should start at the postgraduate level. While four teacher candidates shared the opinion that coding education should be given from primary school, four teacher candidates expressed their opinion that this education should be given at the postgraduate level. $15 \%$ of teacher candidates (six people) expressed their views that teacher candidates should be introduced to coding education while studying undergraduate education at the university. When the opinions on the teaching of coding during secondary and high school years are assessed together, it can be seen that about $65 \%$ of teacher candidates concentrate on these two periods.

The visual results obtained from the Maxqda program for the findings in this section are given below.

It is not a coincidence that the majority of candidate teachers requested in their responses that coding education should be given from the early stages of education life. This is a request that is proportionate to the current living conditions. For example, the candidate teacher coded CT2 responded to the question as follows: "The basic level of education should start from the beginning of elementary school, and coding can be taught in the form of games using ready-made software. Because, today, children began to meet with tablets and computers at the ages of 4 and 5. Whereas, I first had the chance to use my personal computer in my university years.”

Again, as an example, considering the views of candidate teachers coded CT 22, CT 17 and CT27, it is seen in common with all of them that the idea of giving coding education at primary and secondary school level comes to the fore.

CT27: "I think it would be better to give coding course at high school level. Basic computer skills can be acquired and even basic coding can be taught at primary and secondary school level, however, emphasis should be placed on coding education seriously in high school education."

CT22: "I think secondary school is the most suitable period for this education. Children initiate intense relationships with computers in secondary school years."

CT17: "To me, coding is the second step of what needs to be done. In primary school, students can be taught basic knowledge and skills related to computer usage and can be introduced to coding education in secondary school."

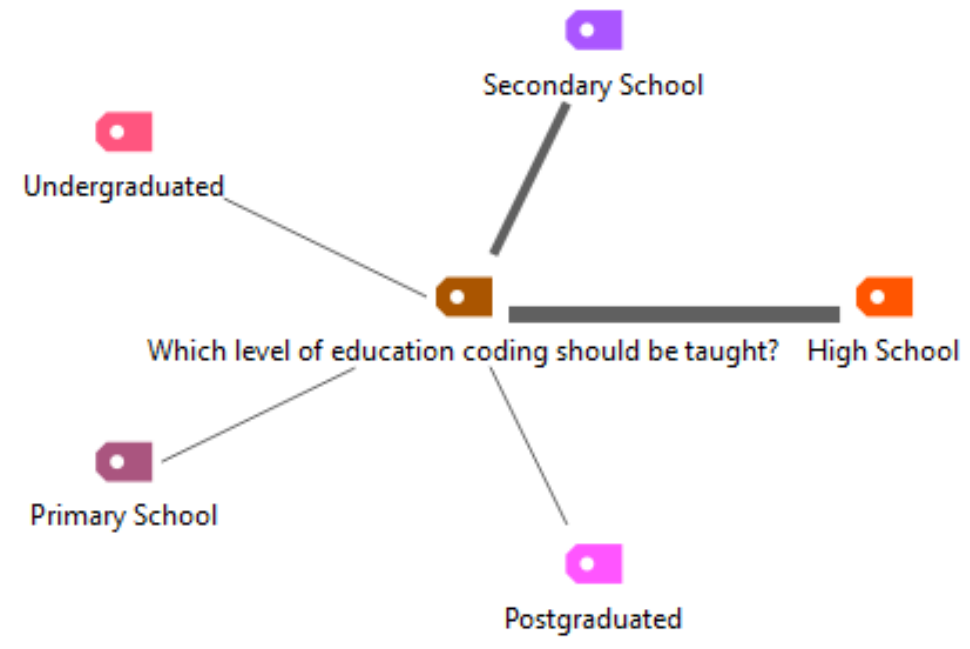

Figure 4. Which level of education should the coding course be given? 


\subsection{Findings on Whether Teacher Candidates Produce Material through Coding}

The answers of teacher candidates to the question of whether they produce material through coding can be seen in Chart 5. According to the responses given, 39 of 40 teacher candidates have not produced any material through coding. Only one teacher candidate stated that he produced material through coding. It is stated that the material produced by the teacher candidate is a simple game produced with "scratch". This result is remarkable. With these findings, it is supported that teacher candidates do not produce material through coding.

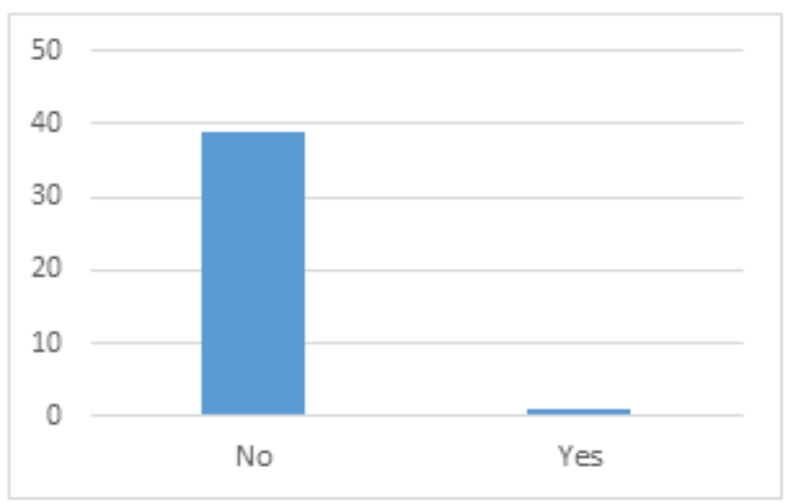

Chart 5. Have you ever produced material through coding?

The views of some candidate teachers on the findings in regard to this part of the research are given below.

The response of the only candidate teacher who produces material by coding is as follows:

CT9: "Yes, however, I produced material using scratch and it was a simple game, a very amateurish one."

When the response is taken into consideration, it is seen that the coded material is very simple and produced with scratch that allows coding with blocks of code without requiring coding knowledge.

CT26: “No, I couldn’t produce any material since I don’t know how to code."

CT14: "This is among the things I always wanted to do, but couldn't have the opportunity yet. However, I couldn't do it until today, since I don't know coding."

CT8: "I couldn't make." Candidate teachers coded CT26, CT14, CT8 and other candidates shared their views that they did not produce material through coding.

In general, it has been observed that candidate teachers cannot produce coding-based material since they do not know how to code. The correctness of the answer to this question was understood from the views of candidate teachers that the second question of the research was directly proportional to the response of the coding level.

In other words, the majority of candidate teachers have expressed their answers to the question that they do not know coding and therefore cannot produce material through coding.

The visual results obtained from the Maxqda program for the findings in this section are given below.

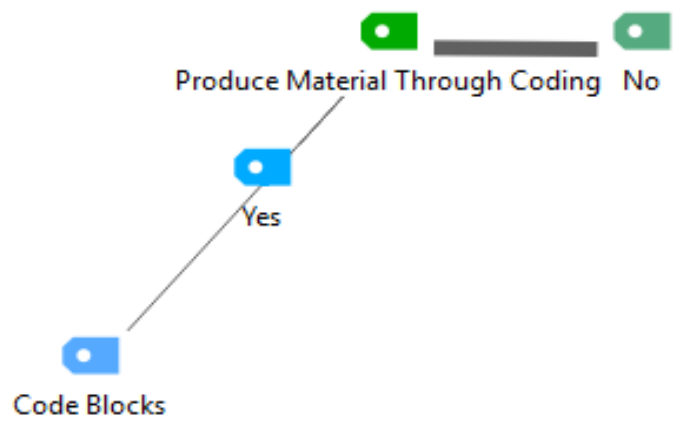

Figure 5. Have you ever produced material through coding?

\subsection{Findings on Teacher Candidates' Views on the Puzzle Produced by Coding}

In Chart 6, the views of teacher candidates on the coding-based puzzle created by the researcher are given in themes.

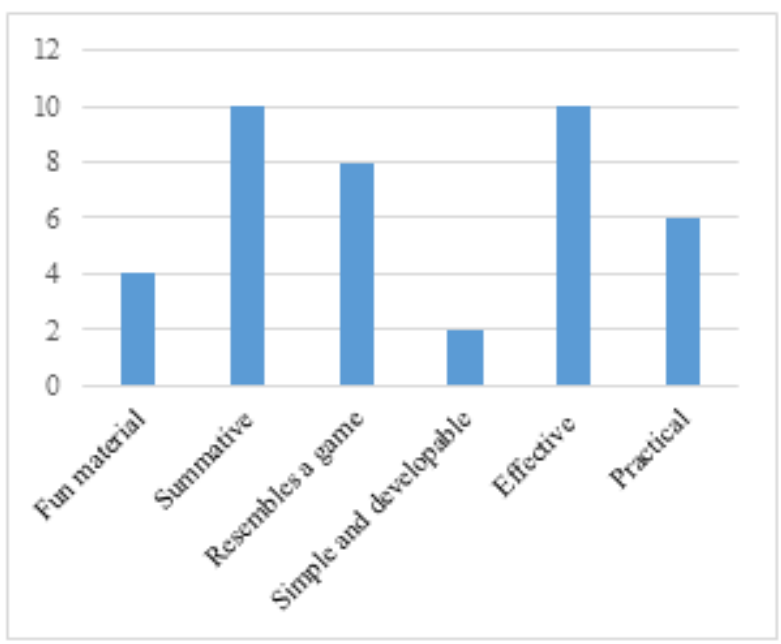

Chart 6. What do you think about the sample material (puzzle) produced by coding?

As a result of the assessment of teacher candidates' views, 6 themes have emerged. 4 out of 40 teacher candidates stated that the puzzle produced by coding is a fun material. 10 teacher candidates stated that the material presented to them by the researchers is an effective teaching material. 10 teacher candidates agreed that the puzzle produced by coding resembles a game. The number of teacher candidates that indicate that the material is simple and can be developed is limited to 2. Another important view indicated about the material is the view of 10 teacher candidates that the material has a summarizing feature. 6 teacher candidates find this material, which is produced by coding, to be practical.

Here, the two views that candidate teachers share most are the views that the puzzle produced by coding is an effective and summative material. Here, the two views that candidate teachers share most are the views that the puzzle 
produced by coding is an effective and summative material. For example, while the candidate teachers coded CT32 and CT36 emphasized these issues, candidate teacher coded CT32 emphasized that this sample material is a material that can summarize an entire unit and give students the information they need to be given in outline. The candidate teacher coded CT 36, on the other hand, stressed that the material is effective because it stimulates the element of curiosity and excitement inherent in human nature. The statements of candidate teachers coded CT32 and CT36 are as follows.

CT32: "I absolutely find it summarizing. Important parts of a unit can be fit into a puzzle as reminder titles."

CT36: "I esteem that it is an effective material because it ignites the curiosity and excites the student.”

The views of the candidate teachers with code CT23 and CT19 were selected among the third and fourth theme categories, which are most emphasized in the material. While the candidate teacher coded CT23 stated the material is practical and the candidate teacher coded CT19 said the material has a game-like aspect with these views:

CT23: "I find it very practical. A single HTML file can be used for all students and can be used over and over again for some units that won't be updated."

CT19: "I think it coding is a game in a way. I believe it will be used and loved by students in the class."

The visual results obtained from the Maxqda program for the findings in this section are given below.

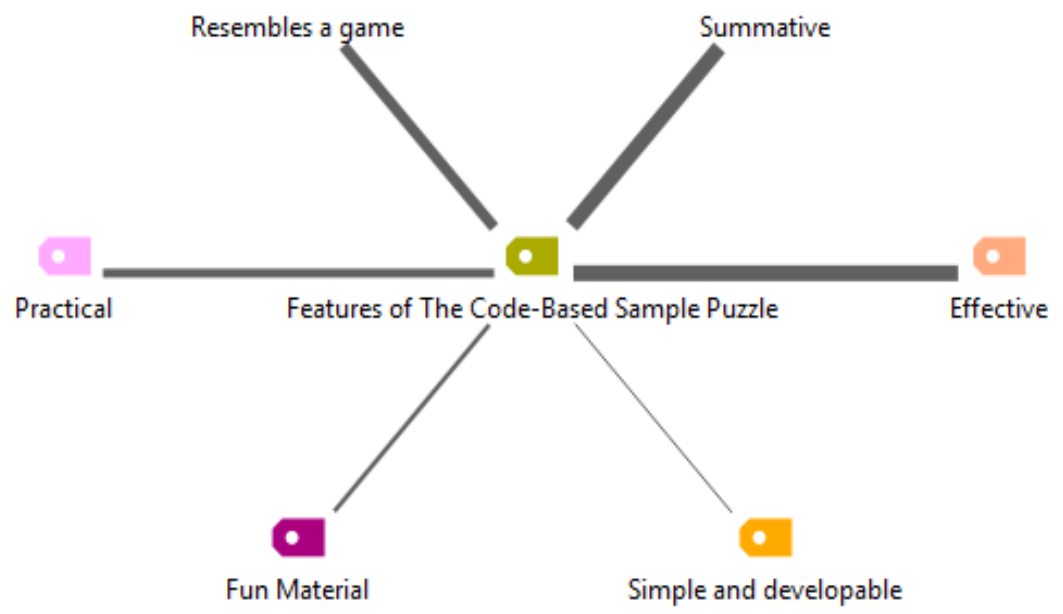

Figure 6. What do you think about the sample material (puzzle) produced by coding?

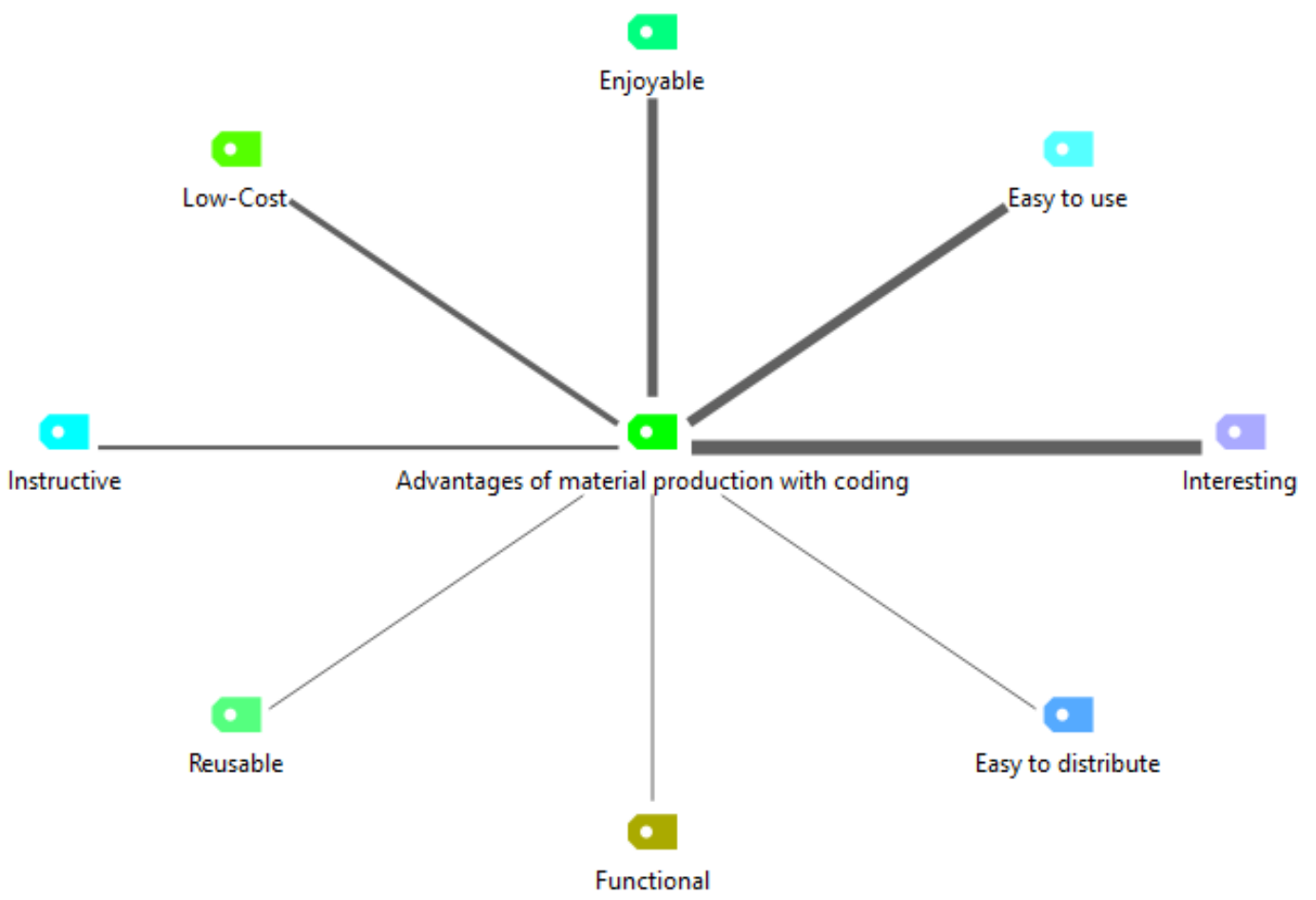

Figure 7. What are the advantages of the research material produced through coding? 


\subsection{Findings on the Advantages of Material Production with Coding}

In Chart 7, there are the themes set in the light of teacher candidates' answers to the question of what kind of advantages the materials produced through coding have. In their responses, 7 teacher candidates stated that the materials produced with coding are enjoyable, 4 teacher candidates stated they are instructive, 5 teacher candidates stated they have low costs, 3 teacher candidates stated that they can be reuse, 8 teacher candidates stated that they can be use easily, 2 teacher candidates stated they are functional, 9 teacher candidates stated they are interesting and 2 teacher candidates stated that they can be distributed easily. According to the views of the teacher candidates, all these features make material production by coding advantageous.

The visual results obtained from the Maxqda program for the findings in this section are given below.

The most important aspects that candidate teachers elaborate on the advantages of coding-based materials are, respectively, that it is interesting, easy to use and fun material. For example, candidate teachers coded CT21 and CT24 used the following statements when emphasizing that such materials attract interest:

CT21: "Unlike ordinary teaching materials, this material will attract students' attention more because it allows the use of Information Technology. In addition, the desire to discover the unknown that I think exists in the students will further increase the interest of the students in such materials. Most of the time you can't find the necessary information directly, such as a book or atlas."

CT24: "When you tell the students that they are going to take a course with computers or tablets and use them in the course, that course attracts the attention of the students very much. Not only the course but the device you use also becomes very interesting and they dedicate themselves to learning more."

The candidate teacher coded CT1, on the other hand, emphasized that the materials produced by coding with the expression "The computer is a very easy material to use for those who know how to use it. My favorite aspect of the materials used in the computer is that they contain descriptive information and they all have the same basic logic. This makes it easy to use and you don't have to make explanations all the time. It automatically redirects the entire class to the correct usage." have the ability to be used easily in general.

Examples of the views of other candidate teachers selected from different theme categories are given below.

CT5: "The ability to produce a wide variety of materials with coding, without a doubt, makes it very functional. The production of materials suitable for every purpose and course seems possible by coding. Of course, the puzzle we examined is a very simple example of this." Here, the candidate teacher coded CT5 refers to the functionality of the materials produced by coding in general sense.

CT11: "You can send the material to all students by e-mail before or after the course, or upload it to a website and open it to the use of all students studying at the same course level or distribute to them. Having a material that is accessible to anyone with access to the web makes the use of the coded material advantageous." The candidate teacher CT11, with his response, refers to the upload of material produced with coding to a host will make it very easy for all the students in the world to reach the material. The sample statements of the candidate teacher coded CT22 with regard to the reuse of materials based on coding, the candidate teacher coded CT28 with regard to the instructiveness of this kind of material, the candidate teacher coded CT34 with the budget friendliness of material produced with coding are as follows.

CT22: "Once coded, it has the advantage of reusing the information again and again until they use their validity. It is a great advantage to know that there is always a material at hand."

CT28: "An average puzzle has enough questions to cover all the topics of a unit. In fact, the puzzle is like a brief summary of each content strand. In this way, if the puzzle is used at the end of the lesson, it has advantages such as being complementary to the lesson, acting as an instructor because it is reinforcing and teaching unlearned information."

CT34: "The ability to coding for someone who knows computer programming is a huge advantage. You can create the material without using any additional material. Considering the cost, we see that it's just the devices used and the time the coder spends."

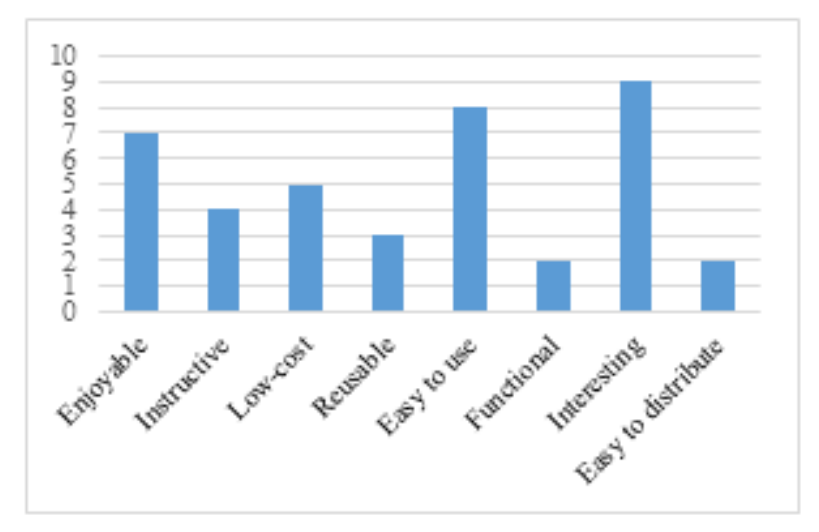

Chart 7. What are the advantages of the research material produced through coding?

\subsection{Findings on the Disadvantages of Material Production with Coding}

12 of the teacher candidates stated that the material produced with coding has a disadvantage as it requires the use of electronic devices. 


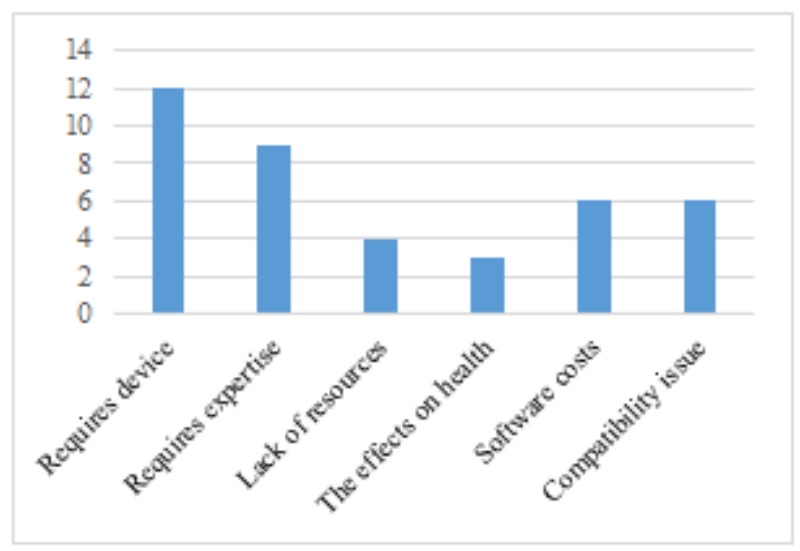

Chart 8. What are the disadvantages of the research material produced through coding?

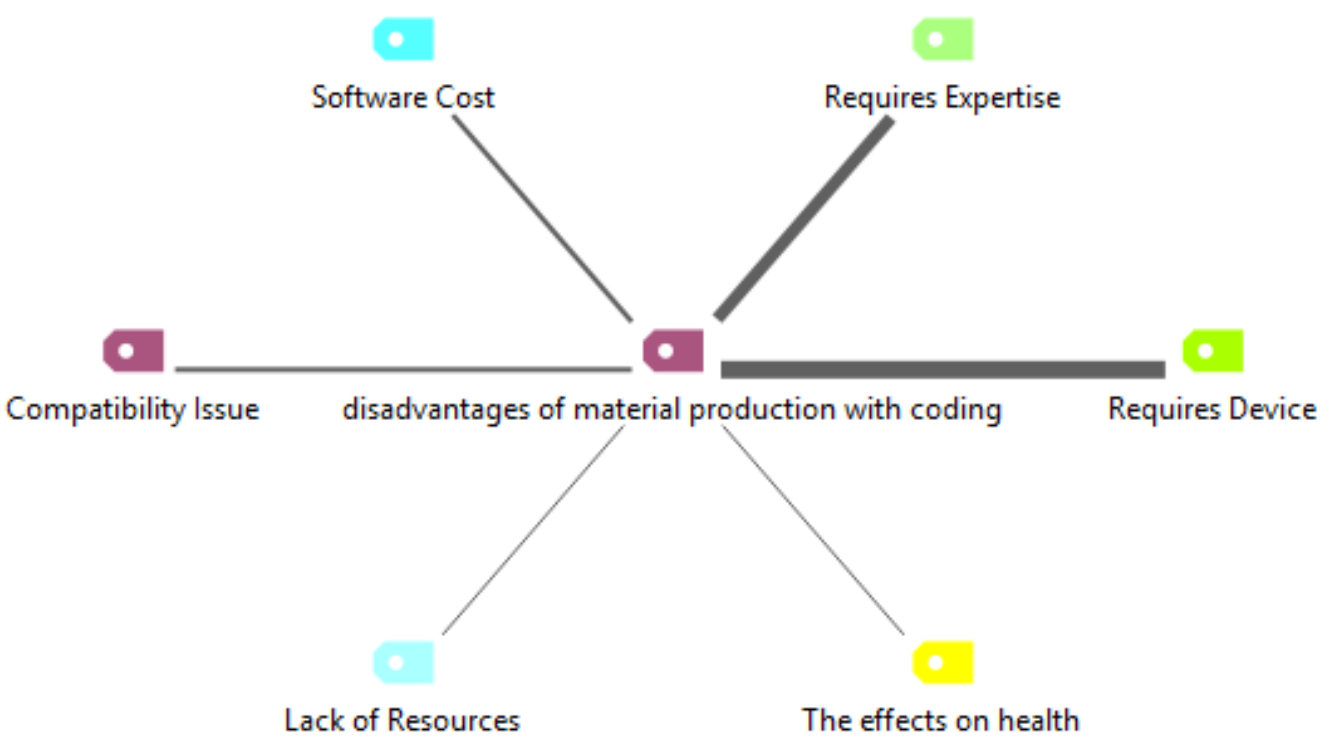

Figure 8. What are the disadvantages of the research material produced through coding?

9 teacher candidates stated that materials produced through coding have disadvantages because of their production and use requires expertise. 4 teacher candidates complained of lack of technical equipment for the use of information resources required for coding and the use of coded material. 3 teacher candidates stated that this situation could adversely affect the students physiologically (effect on health) because the material produced by coding requires the use of electronic devices. While 6 candidate teachers stated that materials produced through coding may face compatibility problems in a variety of devices, six other teacher candidates stated that the prices of materials and software produced through coding are high as shown in Chart 8.

The visual results obtained from the Maxqda program for the findings in this section are given below.

The most important aspects of the disadvantages of coding-based materials candidate teachers put emphasis are the production of coding-based materials requires expertise and the need for devices to use the produced material. The minimum emphasis the candidate teachers put is the impact of electronic devices and materials on human health. The candidate teacher coded CT11 stated that the materials produced by coding have a negative impact on human health in general as follows.

CT11: "The use of coded materials in education provides great advantages for the educational system, but can also cause serious damage to the eye-muscle and skeletal system. We learn that the negative effects of this on health are too serious to be ignored from the news in newspapers and television channels."

Again, the candidate teacher coded CT 39 similarly mentioned that the use of tablet, phone, computer and these kinds of materials have a negative impact on the health of the students and stated that precautions should be taken to minimize these harmful effects during the use of these devices. The expressions of the candidate teacher coded CT 39 are given below.

CT39: "Today we see that most students use glasses and try to deal with arthritis from the early ages. I think that 
some of them are caused by the negative effects of smartphones and computers. These materials should be used with caution.”

The candidate teachers coded CT22 and CT31, on the other hand, mentioned the lack of electronic device laboratories that is still present in today's schools with the following sentences. Although this problem has been overcome in some schools, the situation in the educational institution is still not different from what the candidate teachers coded CT22 and CT 31 mentioned.

CT22: "I think the biggest problem and the disadvantage for us is the lack of devices to use the coded material. Today, there is still not enough devices for every class and every student to use this material. Even if we think about using the material in computer labs at schools, it would still be too difficult. Because the laboratories usually do not have as many devices as the class population. In fact, most schools only have 8 to 10 computers. I came across a similar situation at the school where I did my internship.”

CT31: "In schools, we can only use such materials in classrooms by connecting a single computer to a projector. It is a little difficult to use them on one-to-one basis because there aren't as many computers as the students in the classroom. Even if it is given as homework, we still have students who don't have computers at home."

The CT4 coded candidate teacher stated that he did not know the coding with the answer "Considering the fact that we don't know coding and that we can't learn in the short term, we can only use ready-to-use software. Who can take this burden on himself? I don't know" and stated that the problem could be overcome using ready software, but this situation brought a certain material burden.

\section{Conclusions and Discussion}

As a result of the research, it was first concluded that a few teacher candidates have knowledge of what is coding from the definitions they made about coding. All of the four different themes produced by teacher candidates are related to the definition of coding. But among the responses, there was no expression that defines the coding flawlessly.

The second result from the study showed that 36 of 40 teacher candidates do not know coding. Considering that coding is one of the 21st century skills, this is a major shortcoming. There is a misconception among teacher candidates that teaching coding to the students is the duty of the information technologies teacher. Considering the requirements of the age in which we live, it is a requirement for each teacher and teacher candidate to have basic coding skills [24]. Almost all of the electronic devices around us are operating with a coding language. This includes the electronic devices that we use in the educational environment. Considering that professionally competent teachers can provide positive learning conditions for students, there is a need for in-service training for the teacher who is with student groups with different characteristics (different age, socio-economic level and different interests). According to Seferoğlu, in-service trainings are ideal activities for the elimination of such deficiencies. In addition, teachers can update their own equipment without waiting for in-service training and gain skills appropriate to the educational system of the age [26]. Coding can be taught to teachers with in-service training. In addition, in all branches raising teachers, giving the coding class to teacher candidates is essential in terms of the conditions of the age in which we live [24].

The third result obtained from the research is actually an indication of this necessity. The majority of teacher candidates want to gain the ability of coding, that is, to learn coding. According to İnci and Kandır [15], because teachers are the ones to use this digital technology product in the educational environment, their willingness and positive attitude are very important. However, since the teacher candidates who are subject to the research are already graduated from faculties, they will either have to learn coding through their own means before starting the profession or they will have to acquire this skill through in-service training after they become teachers.

According to the results of the study's fourth problem, the majority of teacher candidates stated that coding education should be given in high school years. Again, an important part of the candidate teachers expressed their views on starting this education in secondary schools. As a result of the research carried out by Göncü, Çetin and Top[13], with the computer and instructional technologies department teacher candidates, they obtained evidence that teacher candidates have a belief that coding education should be given at each level of education. Today, in many country, the coding education starts at primary schools. Sayın and Seferoglu stated that the Ministry of National Education made a decision to start providing information technologies and software courses from the fifth grade in the 2012-2013 academic year and emphasized that it would be beneficial to use social coding environments in this context [24]. This explains the results obtained from the research. Coding education should be given from the first step of education to the last step of higher education, gradually increasing difficulty and from simple to complex. Thus, students will not be directly confronted with complex coding languages and will learn coding with simple code blocks. At the same time, a code training from simple to complex will prevent students from developing negative attitudes towards coding.

As a result of the research, the result obtained is remarkable that none of the other teacher candidates, except one teacher candidate, produced material through coding. Today, coding based material production is very easy. Even teachers with no coding knowledge can code simple materials by using programs such as scratch that allow coding with code blocks. Or they can easily produce 
these materials using ready-to-use software. In particular, applications that offer the opportunity to work with code blocks, such as scratch, offer the opportunity to the student to have fun while learning. Code blocks can be easily used by students and teachers who do not know any coding with drag-and-drop method [2]. Again, Code.org is another application that is prepared for a similar purpose and teaches children coding while playing games [1].

Another result obtained from the research is that teacher candidates found the puzzle produced by coding to be fun, effective, simple and developable. They have stated that the puzzle that resembles a game can give the student pages of information in a summarized form. The results obtained from the research that coding with coding tools is fun, simple and exciting, and that students can develop very different skills including creativity and can be used effectively in the educational environment, are consistent with the views and studies of the various researchers $[2,12,15,21]$.

Another result obtained from the research is that the teacher candidates think that the materials produced by coding will be used in the teaching environment is advantageous because it is fun, instructive, low-cost, reusable, functional, easy to distribute and has interesting features. If the educational materials produced with coding are coded by the teachers, students can acquire them free of charge as well as use them countless times. They can make their materials online and distribute them to students and teachers around the world. These applications allow students who spend most of the day with mobile devices to learn by playing games. These materials, which present the essence of the subject to the student and Djenic and Mitic [8] speak of as multimedia tools, address the students' senses with their graphics, sounds and logical editing, and play a major role in maintaining the learned information.

The final result of the study was that the views of teacher candidates on the disadvantages of materials produced through coding require electronic devices and technical equipment, lack of technical equipment in education environments, the high cost of using ready software, software compatibility problems and negative effects of electronic devices on the physiological state of students. Scratch, Code.org, Blockly, Code Combat, and Thimble by Mozilla are some of the free software that works on different operating systems such as Mac/Linux and Windows $[2,16,27]$. In addition, to prevent health problems caused by the use of computers or mobile devices, long-term use should be avoided, various stretching movements should be done and eye-screen distance and posture position should be adjusted well [22].

In conclusion, it was seen that the candidate teachers who will become the teachers of the future have stated that coding education, which begins to take part in today's education programs, but wasn't present in the curriculum in the recent past, should be given to students starting from the first years of teaching, and that they do not know coding, however, in this study, where they demonstrated their willingness to learn, it was observed that they were looking at the production of materials with coding, that they found the sample material advantageous and that they were convinced that the use of these materials would contribute positively to the educational environment. The disadvantages expressed by candidate teachers in their views on such materials are usually related to material problems or problems that may be overcome by some measures. These kinds of materials are valuable materials that can provide students and even teachers with the opportunity to learn by living and embodying abstract concepts, and they must be used strictly in the educational environment.

Considering the findings obtained as a result of the research, the lack of coding for candidate teachers is a situation which cannot be tolerated in today's world. In the use of such materials that prepare the basis for active learning, the teacher is obliged to guide the students and make explanations when necessary [39]. However, teachers who know how to code can help their students prepare coding materials, or they can enrich the teaching environment by preparing their designs themselves.

\section{Acknowledgements}

I would like to thank all teacher candidates who participated in the research.

\section{REFERENCES}

[1] Aytekin, A., Sönmez Çakır, F., Yücel, Y. B., Kulaözü, İ. (2018). Geleceğe yön veren kodlama bilimi ve kodlama öğrenmede kullanılabilecek bazı yöntemler. Avrasya Sosyal ve Ekonomi Araştırmaları Dergisi, 5(5), 24-41.

[2] Baz, F. Ç. (2018). Çocuklar için kodlama yazılımları üzerine karşılaştırmalı bir inceleme. Curr Res Educ, 4(1), 36-47.

[3] Berg, B. L., Lune, H. (2015). Görüşmeye Tiyatral Bir Bakış (I. Som and G. Ekşi, Translator). in H. Aydın (Ed.), Sosyal Bilimlerde Nitel Araştırma Yöntemleri. 129-188. Konya: Eğitim Yayınevi.

[4] Budak, Y., Çoban Budak, E. (2012). Öğrencilerin Bilgisayar Destekli Eğitim Hakkındaki Yargıları ve BDE İLE Temel Bilgisayar Bilgisi Öğretiminin Etkinliği. Eğitim ve Öğretim Araştırmaları Dergisi, 1(3), 123-129.

[5] Büyüköztürk, Ş., K1lıç Çakmak, E., Akgün, Ö.E., Karadeniz, Ş., Demirel, F., (2011). Bilimsel Araştırma Yöntemleri. Ankara: Pegem Akademi Yayınları.

[6] MEB, (2012). Görüşme Teknikleri. Ankara: Milli Eğitim Bakanlığı Yayınları (http://www.megep.meb.gov.tr/mte_pr ogram_modul/moduller_pdf/G\%C3\%B6r\%C3\%BC\%C5\% 9Fme\%20Teknikleri.pdf) 
[7] Demirer V., Sak, N. (2016). Dünyada ve Türkiye'de Programlama Eğitimi ve Yeni Yaklaşımlar. Eğitimde Kuram ve Uygulama, 12(3), 521-546.

[8] Djenic, S., \& Mitic, J. (2017). Teaching Strategies and Methods in Modern Environments for Learning of Programming. International Association for Development of the Information Society. (IADIS) International Conference on Cognition and Exploratory Learning in Digital Age 14th, (pp. 189-196), Vilamoura, Algarve, Portugal, Oct 18-20, 2017. Derive from: https://files.eric.ed.gov/fulltext/ED5794 55.pdf

[9] Durak, H., Karaoğlan Y1lmaz, G., Y1lmaz, R., Seferoğlu, S.S. (2017). Erken Yaşta Programlama Eğitimi: Araştırmalardaki güncel eğilimlerle ilgili bir inceleme. In H. F. Odabaşı, B. Akkoyunlu ve A, İşman (Ed). Eğitim Teknolojileri Okumaları 2017, (12th Part, pp. 205-236) Tojet ve Sakarya Üniversitesi, Adapazar1.(Online:http://yunus.hacettepe.edu. tr/ sadi/yayin/Kitap_ETO2017_Bolum12_205-236_Erken YastaProgramla.pdf - Access: 11.08.2018.)

[10] Engin, A. O., Tösten, R., \& Kaya, M. D. (2010). Bilgisayar destekli eğitim. Kafkas Üniversitesi Sosyal Bilimler Enstitü Dergisi, 1(5), 69-80.

[11] Ersoy, H., Madran, R. O., Gülbahar, Y. (2011). Programlama Dilleri Öğretimine Bir Model Önerisi: Robot Programlama. XIII. Akademik Bilişim Konferansl, (pp. 731-736), 2-4 Şubat, Inönü University, Malatya, Turkey.

[12] Genç, Z., Karakuş, S. (2011). Tasarımla öğrenme: eğitsel bilgisayar oyunları tasarımında scratch kullanımı. 5th International Computer \& Instructional Technologies Symposium, (pp. 981-987), 22-24 September 2011, Firat University, Elazığ, Turkey.

[13] Göncü, A., Çetin, İ., Top, E. (2018). Öğretmen adaylarının kodlama eğitimine yönelik görüşleri: bir durum çalışması. Mehmet Akif Ersoy Üniversitesi Eğitim Fakültesi Dergisi, (48), 85-110. Retrieved from http://dergipark.gov.tr/maeuef d/issue/39596/334560

[14] Güzeller, C., Korkmaz, Ö. (2007). Bilgisayar destekli öğretimde bir ders yazılımı değerlendirmesi. Kastamonu Eğitim Dergisi, 15(1): 155-168.

[15] İnci, M. A, Kandır, A. (2017). Okul öncesi eğitim'de dijital teknolojinin kullanımıyla ilgili bilimsel çalışmaların değerlendirilmesi. Hitit Üniversitesi Sosyal Bilimler Enstitüsü Dergisi, Y1l 10, Say1 2, Aralı 2017, ss.1705-1724.

[16] Jenkins, C. W. (2017). Classroom talk and computational thinking. International Journal of Computer Science Education in Schools, Oct 2017, Vol. 1, No. 4 ISSN 2513-8359. DOI: 10.21585/ijcses.v1i4.15 (Derive from: https://files.eric.ed.gov/fulltext/ED581597.pdf)

[17] Karabak, D., Güneş, A. (2013). Ortaokul birinci sınıf öğrencileri için yazılım geliştirme müfredat önerisi. Ĕgitim ve Öğretim Araştırmaları Dergisi, 2(3), 163-169.

[18] MEB, (2007). Megep (mesleki eğitim ve öğretim sisteminin güçlendirilmesi projesi) bilişim teknolojileri programlama temelleri. Ankara: Milli Eğitim Bakanlığı Yayınları.

[19] MEB, (2018) Bilişim teknolojileri ve yazılım dersi öğretim programı (ortaokul 5 ve 6. sinıflar), Ankara: Milli Eğitim Bakanlığı, Retrieved From:(http://mufredat.meb.gov.tr/Dos
yalar/2018124103559587-Bili\%C5\%9Fim\%20Teknolojiler i\%20ve\%20Yaz\%C4\%B1l\%C4\%B1m\%205-6.\%20S\%C4 \%B1n\%C4\%B1flar.pdf -Access 17.08.2018).

[20] Miles, M. B., Huberman, A.M. (1994). Qualitive data analysis (2nd ed). California: SAGE.

[21] Odac1, M. M., Uzun, E. (2017). Okul öncesinde kodlama eğitimi ve kullanılabilecek araçlar hakkında bilişim teknolojileri öğretmenlerinin görüşleri: bir durum çalışması, 11. Uluslararası Bilgisayar ve Öğretim Teknolojileri Sempozyumu, (pp. 718-725), 24-26 Mayıs, Inönü University, Malatya, Turkey.

[22] Sayan, H. (2016). Okul öncesi eğitimde teknoloji kullanım1. 21. Yüzyılda Eğitim Ve Toplum Eğitim Bilimleri Ve Sosyal Araștırmalar Dergisi, 5(13), 67-83. (Retrieved From: http://dergipark.gov.tr/download/article-file/367647)

[23] Saygıner, Ş., Tüzün, H. (2017) Erken yaşta programlama eğitimi: yurt dışı ve yurt içi perspektiflerinden bır bakış, 11 . Uluslararast Bilgisayar ve Öğretim Teknolojileri Sempozyumu, (pp. 64-72), 24-26 Mayıs, Inönü University, Malatya, Turkey.

[24] Sayın, Z. ve Seferoğlu, S. S. (2016). Kodlama eğitimi ve kodlamanın eğitim politikalarına etkisi. XVIII. Akademik Bilişim Konferansı (AB16), (pp. 1-13), 3-5 Şubat 2016, Adnan Menderes Üniversitesi, Aydın. Derive from: http://yunus.hacettepe.edu.tr/ sadi/yayin/AB16_Sayin-Sefe roglu_Kodlama.pdf).

[25] Shachter, R. (2011). How to use technology to connect your students to a larger world. Kid to Kid Connections, 1-3. Derive from http://files.eric.ed.gov/fulltext/EJ945712.pdf .

[26] Seferoğlu, S. S. (2004). Öğretmen yeterlikleri ve mesleki gelişim. Bilim ve Aklın Aydınlığında Ĕ̈itim, 58, 40-45.

[27] Wilson, A., \& Moffat, D. C. (2010). Evaluating scratch to introduce younger schoolchildren to programming. Paper presented at 22nd Annual Workshop of the Psychology of Programming Interest Group, Leganés, Spain. (Retrieved from:http://scratched.gse.harvard.edu/sites/default/files/wils on-moffat-ppig2010-final.pdf)

[28] Yıldırım, A. ve Şimşek, H. (2006). Sosyal bilimlerde nitel araştırma yöntemleri (5 $5^{\text {th }}$ Edition). Ankara: Seçkin Yayınevi.

[29] Alaaddin Keykubat University, Çocuklar için kodlama eğitimi.https://alkusem.alanya.edu.tr/ctrcms/media/44/tmp/ doc/Cocuklar\%20i\%C3\%A7in\%20Kodlama\%20Egitimi.pd $\mathrm{f}$

[30] Kaya, Z. (2006). Öğretim Teknolojileri ve Materyal Geliştirme, Ankara: Pegem A Yayıncılık.

[31] Usta, E. (2015) Öğretmen Adaylarının Öğretim Materyalleri Geliştirme Süreçlerinin Görsel Ve Mesaj Tasarımı İlkeleri Açısından İncelenmesi, Gazi Eğitim Bilimleri Dergisi, 1(1), 1-14.D

[32] Kobak-Demir, M., Gür, H. (2018). Teknoloji Destekli Öğretim Materyalleri WebQuestlerin Yeterliklerini Yordayan Değişkenler, Balıkesir Üniversitesi Fen Bilimleri Enstitüsü Dergisi, 20(1), 156-173.

[33] Tunç, Y. \& Kıncal, R. Y. (2018). Okul Öncesinde Kodlamanın Önemi ve Kodlama Eğitimlerinde Kullanılan Araç ve Uygulamaların İ́ncelenmesi. II. Uluslararası 
Multidisipliner Çalışmalar Kongresi. 4-5 Mayıs 2018, Adana, Türkiye.

[34] Yiğit, N. (2002). Bilgisayar Destekli Kullanım Dersine Yönelik Bir Rehber Materyal Geliştirme Çalışması: Öğretmen Eğitimi II, V. Ulusal Fen Bilimleri Ve Matematik Eğitimi Kongresi, Orta Doğu Teknik Üniversitesi, 16-18 Eylül 2002, Ankara, Türkiye.

[35] Merriam, S. (1998). Qualitative research and case study applications in education. Revised and expanded from case study research in education. USA: JB Printing.

[36] Karadağ, R. (2014). Okuma İlgisi, Tutumları ve Alışkanlığı Konusunda Yapılmış Çalışmaların Lisansüstü Tezlere Dayalı Analizi: YÖK ve ProQuest Veri Tabanları Örneklemi, Pamukkale Üniversitesi Eğitim Fakültesi Dergisi, 35(1), 1-17.

[37] Demirci, S., Köseli, M. (2014). İkincil Veri ve İçerik Analizi. K. Böke (Ed.), Sosyal Bilimlerde Araştırma Yöntemleri, 320-364. İstanbul: Alfa Yayınları.

[38] Berg, B. L., Lune, H. (2015). İçerik Analizine Giriş (Z. E. Özcan, Translator). in H. Aydın (Ed.), Sosyal Bilimlerde Nitel Araştırma Yöntemleri. 380-417. Konya: Eğitim Yayınevi.

[39] Ün Açıkgöz, K. (2009). Aktif Öğrenme. İzmir: Biliş Yayınları.

[40] Eclipse Crossword Package Program (https://www.eclipsecrossword.com/) 